\title{
Discovering the Riches of the Word
}

\author{
Religious Reading in Late Medieval and \\ Early Modern Europe
}

\author{
Edited by
}

Sabrina Corbellini

Margriet Hoogvliet

Bart Ramakers

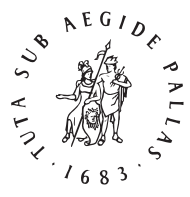

B R I L L

LEIDEN | BOSTON

For use by the Author only | (C) 2015 Koninklijke Brill NV 


\section{Contents}

Notes on the Editors vii

Notes on the Contributors viii

List of Illustrations $\quad \mathrm{X}$

Introduction: Discovering the Riches of the Word 1

Sabrina Corbellini, Margriet Hoogvliet, Bart Ramakers

1 Approaching Lay Readership of Middle Dutch Bibles: On the Uses of Archival Sources and Bible Manuscripts $\quad 18$

Suzan Folkerts

2 Manuscript Paratexts in the Making: British Library Ms Harley 6333 as a Liturgical Compilation 44

Matti Peikola

3 Uncovering the Presence: Religious Literacies in Late Medieval

Italy 68

Sabrina Corbellini

4 Evidence for Religious Reading Practice and Experience in Times of Change: Some Models Provided by Late Medieval Texts of the Ten Commandments 88

Elisabeth Salter

5 'Car Dieu veult estre serui de tous estaz': Encouraging and Instructing Laypeople in French from the Late Middle Ages to the Early Sixteenth Century 111

Margriet Hoogvliet

6 Books, Beads and Bitterness: Making Sense of Gifts in Two Table Plays by Cornelis Everaert 141

Bart Ramakers

7 Some Aspects of Male and Female Readers of the Printed Bible Historiale in the Sixteenth and Seventeenth Centuries $\quad 171$

Éléonore Fournié 
8 From Nicholas Love's Mirror to John Heigham's Life: Paratextual Displacements and Displaced Readers 190 Ian Johnson

9 Vernacular Biblical Literature in Sixteenth-Century Italy: Universal Reading and Specific Readers 213 Élise Boillet

10 The Catholic Church and the Vernacular Bible in the Low Countries: A Paradigm Shift in the 1550s? 234 Wim François

$11 \quad$ Reading the Crucifixion in Tudor England 282 Lucy Wooding

12 The Other Nicodemus: Nicodemus in Italian Religious Writings Previous and Contemporary to Calvin's Excuse à Messieurs les Nicodémites (1544) 311 Federico Zuliani

13 'What's Learnt in the Cradle Lasts till the Tomb': Counter-Reformation Strategies in the Southern Low Countries to Entice the Youth into Religious Reading 335 Hubert Meeus

Index Nominum $\quad 363$ 


\title{
Books, Beads and Bitterness: Making Sense of Gifts in Two Table Plays by Cornelis Everaert
}

\author{
Bart Ramakers
}

Like all other authors in their time, historical playwrights were readers. They did not compose their plays ex nihilo, but were inspired by, and made use of, what they had read or what had been read to them, and by what they had seen or otherwise perceived. Then, like now, being literate entailed more than just being able to read and write. Literacy also meant the ability to understand other forms of communication, including visual and body language - and, for that matter, drama. It was especially the practice of this genre that required authors not only to read and write, but also to speak, to listen and to see, with which is meant not just the ability to use the senses per se, but to use them coherently, for whatever purpose, intellectual or otherwise. Of course, the same applies to viewers or spectators. They, too, had to be literate in all the aforementioned ways.

The definition of literacy as a composite activity has led scholars in modern literacy studies to speak of 'performative literacy', by which they mean a set of reading practices through which readers can grow in knowledge and literacy. ${ }^{1}$ These practices or actions include, among others, a capacity for sustained attention while reading, the willingness to read and reread repeatedly, and the ability to argue for a particular reading of a text, but at the same time be open to an alternative one. ${ }^{2}$ Being literate in this sense means one treats reading, like writing, as a process of textual construction, whereby the meaning process may eventually be visualized through writing. ${ }^{3}$

This concept of performative literacy is much akin to that of "performative reading', a term used to describe historical, especially medieval, reading practices. ${ }^{4}$ It can be defined as a way of reading that invites an active process of

1 Blau S., "Performative Literacy: The Habits of Mind of Highly Literate Readers", Voices from the Middle 10 (2003) 18-21.

2 Blau, "Performative Literacy" 19-21.

3 Blau, "Performative Literacy" 21.

4 Brantley J., Reading in the Wilderness. Private Devotion and Public Performance in Late Medieval England (Chicago \& London: 2007) 1-6, 14-16; Gertzman E., "Introduction: the spectrum of 
reenactment, ${ }^{5}$ the result of which is not only the constitution of meaning, but also the affirmation of individual and cultural values. ${ }^{6}$ Studying performative reading is not as much about the meaning of the text as it is about the reader's response to a combination of text and images, and in addition to rubrics and layout (mise-en-page). ${ }^{7}$ This response, often intended and explicitly required by the text, can be very active and practical, especially where devotional texts are concerned.

A third term, recently developed in medieval theatre studies and informed by cognitive theory, is that of 'performance literacy'. ${ }^{8}$ The word 'literacy' here does not refer so much to reading, but to seeing, the term denoting a strategy of seeing whereby laypeople derive devotional meaning from their encounter with an image's material presence. They are able, or they learn or are taught to be able (hence the word 'literacy') to engage, on a regular basis, with their bodies (hence the word 'performance') in rituals or devotional practices visà-vis images (statues as well as paintings and prints) that reflect, assume and activate that same corporeality, because they are (representations of) bodies themselves - of Christ, of Mary or of some saint. It is supposed that historical drama stimulated this particular kind of literacy by providing models for these encounters. $^{9}$

\section{Aim and Set-up}

This paper aims to illustrate all three types of reading or literacy with plays by Cornelis Everaert (d. 1556), a member and possibly the principal poetfactor - of the chambers of rhetoric The Holy Ghost and The Three Saints from Bruges. Everaert earned a living as a fuller and dyer, but also acted as a clerk of the Bruges drapers' guild and of the city's archers' guild of St Sebastian. He is the author of a substantial body of work for the stage ( 35 plays in all), written and performed in the first three decades of the sixteenth century, handed

performances", in Gertsman E. (ed.), Visualizing Medieval Performance. Perspectives, Histories, Contexts (Aldershot - Burlington, VT: 2008) 1-13; Sheingorn P., "Performing the illustrated manuscript: great reckonings in little books”, in Gertsman, Visualizing, $57-82$, here $57-58$.

5 Gertsman, "Introduction" 1.

6 Gertsman, "Introduction" 2.

7 Gertsman, "Introduction" 4.

8 Stevenson J., Performance, Cognitive Theory, and Devotional Culture. Sensual Piety in Late Medieval York (New York: 2010) 9, 41-43, passim. Also see Brantley, Reading 7-8.

9 Stevenson, Performance 2, 12, 15-16, 24, passim. On this subject also see Newman B., "What Did It Mean to Say 'I Saw'?”, Speculum 8o (2005), 1-43, here 16. 
down in a carefully written manuscript, now in the Royal Library of Belgium in Brussels..$^{10}$ Although a minority of his plays are on comical, political, dynastical and socio-critical subject matters, his dramatic oeuvre mainly consists of religious plays. ${ }^{11}$ This concerns plays that are attached to, and are predominantly written for, the observation of central devotions, or address religious life more or less directly: a Biblical play, a miracle play, a morality play, five so-called comparaties ('comparations' or 'comparisons') ${ }^{12}$ and seven so-called tafelspelen ('table plays'). ${ }^{13}$ The latter are short allegorical plays performed indoors, during a banquet. Table plays were often called 'present plays', because they were geared towards and culminated in the presentation of a gift to the person or persons in whose honour the banquet was given. That might be a newlywed couple, but also, as is the case with Everaert's plays, a newly ordained priest, a Franciscan tertiary celebrating his fiftieth jubilee of religious life, or the newly installed king of a trade or militia guild. Everaert wrote five table plays on the occasion of such installations, which took place during these guilds' annual feasts, usually the feast days of their patron saints. The guilds involved were the already mentioned guild of St George, the Bruges milliners' guild and the chamber of rhetoric The Holy Ghost itself. ${ }^{14}$

10 For an edition of Everaert's plays according to the Brussels manuscript as well as the most recent biographical and bibliographical information on the author, see Hüsken W.M.H. (ed.), De Spelen van Cornelis Everaert, 2 vols. (Hilversum: 2005). Further information on the plays in Hüsken W., "Cornelis Everaert and the community of late medieval Bruges", in Hindley A. (ed.), Drama and Community. People and Plays in Medieval Europe, Medieval Texts and Cultures of Northern Europe 1 (Turnhout: 1999) 110-125.

11 For a discussion of those plays written on political and dynastical events, see Mareel S., Voor vorst en stad. Rederijkersliteratuur en vorstenfeest in Vlaanderen en Brabant (14321561) (Amsterdam: 2010).

12 Ramakers B., "Discerning Vision. Cognitive Strategies in Cornelis Everaert's Mary Compared to the Light (c. 1511)", in Melion W.S. - Wandel L.P. (eds.), Image Theory and Incarnation Doctrine, Intersections: Interdisciplinary Studies in Early Modern Culture (Leiden - Boston: 2015) (forthcoming).

13 On the genre generally, see Pikhaus P., Het tafelspel bij de rederijkers, 2 vols. (Ghent: 1988). The eight table plays are numbered ${ }_{1} \mathrm{~B}_{15}, \mathrm{1B}_{24}, 1 \mathrm{~B}_{2} 6,1 \mathrm{~B}_{2} 7, \mathrm{1B}_{29}, 1 \mathrm{~B}_{31}, \mathrm{BB}_{32}$, and $\mathrm{1B}_{34}$ in Hummelen W.M.H., Repertorium van het rederijkerdrama 150o-ca. 1620 (Assen: 1968). Also see Pikhaus, Tafelspel 39-40. For editions of these plays, see Hüsken, Spelen I, no. XIV; II, nos. XXIII, XXV, XXVI, XXVIII, XXX, XXXI, XXXIII. As a matter of fact, according to Hüsken, one play is not a real table play. Hüsken W., "De gelegenheidsdichter Cornelis Everaert en zijn tafelspelen in enge en ruimere zin”, Verslagen en Mededelingen van de Koninklijke Academie voor Nederlandse Taal- en Letterkunde (1992) 62-78, here 73.

14 Two of the guilds for which he wrote table plays are not identified in the text of the plays. 
It is especially in his comparaties that Everaert's erudition is revealed in full glory, because in them he demonstrates a wealth of knowledge of the physical (both natural and man-made) and metaphysical realms-knowledge he must have at least partly acquired through reading. ${ }^{15}$ Here, however, we will deal with two of his table plays. These lead us to the heart of late medieval lay piety, that is to the devotion to Christ and Mary, two devotions which, of course, were strongly intertwined, and moreover were embedded in local Bruges observances. Like in so many other cities, public veneration of both Mother and Son manifested itself almost on a daily basis. Bruges knew a special veneration of the Passion of Christ through the relic of the Holy Blood. ${ }^{16}$

The plays in question demonstrate Everaert's performative literacy, in the sense that they were clearly informed by his reading experience of devotional treatises and by his ability to visualize this experience through writing, in this case through the composition of these two plays. The treatises involved called for a performative reading, which, as previously stated, is to say that they invited an active process of reenactment. Finally, the plays stimulated the audience's performance literacy, in the sense that they demonstrated how to encounter and deal with an object's (or image's) material actuality, in casu dealing with the gift that was presented.

Making sense of these gifts in an intellectual manner of course implied the active use on behalf of the audience of the senses of sight and hearing, so elementary to the understanding of drama in general. But in the case of these particular plays the senses of smell, taste and touch were referred to as well. Not that the banqueters were asked to actually smell, taste and touch the objects revealed and presented in the course of the action, but explicit reference is made to their sensual characteristics, which the spectators knew about through either reading or experience, or both. What we are dealing with in Everaert's table plays is what Elizabeth Williamson succinctly circumscribes as 'properties in action' or 'the materials of performance.' ${ }^{17}$ In daily life the use of these material objects, some devotional in nature, was closely intertwined with the-sometimes systematic—reading of devotional texts, including

\footnotetext{
15 Ramakers, "Discerning Vision".

16 Brown A., Civic Ceremony and Religion in Medieval Bruges c. 1300-1520 (Cambridge: 2011) passim. On manifestations of the city's Marian devotion, see Strohm R., Music in Late Medieval Bruges (Oxford: 1990) passim.

17 Williamson E., "Mere Properties. The Materiality of Religious Objects", in Williamson E. (ed.), The Materiality of Religion in Early Modern English Drama (Farnham - Burlington, VT: 2009) 1-32, here 23, 27.
} 
prayer and contemplation. ${ }^{18}$ Not only was this reading performative in character, it also was informed by performative and performance literacy in the aforementioned meanings. In their descriptive and explanatory technique, the plays clearly build on the audience's devotional reading experiences. It is even possible that in the case of one play an actual book or booklet was presented, and thus functioned as property in action or as material in performance.

\section{A Rosary}

In the first play, called Een Tafelspeilken up een Hoedeken van Marye (A Table Play on the Chaplet of Mary) ${ }_{1}^{19}$ the gift is a rosary, which in the course of the play is handed to the newly installed king of the Bruges milliners' guild. Probably the play was performed during the guild's ${ }_{1531}$ Epiphany banquet. ${ }^{20}$ According to a stage direction, the rosary was contained in 'a small case or casket' ('een cleen cofferkin ofte forchierkin'; after v. 195). According to that same stage direction the rosary itself consisted of either coral or amber beads. ${ }^{21}$ In dealing with this play and the way it was perceived, it is necessary to stress that the meaning of the rosary was not in the object as such, but in the context; that is, in the performance of the act of praying and meditation that the use

18 On these objects as material expressions of religion, see Keenan W.J.F. - Arweck E., "Introduction: Material Varieties of Religious Expression", in Arweck E. - Keenan W.J.F. (eds.), Materializing Religion. Expression, Performance and Ritual (Farnham - Burlington, VT: 2006) 1-20.

19 Hüsken, Spelen II, 785-802, no. Xxv. Everaert wrote another play on the rosary, Tspel van Maria Hoedeken; Hüsken, Spelen I, 74-126, no. I. Also see on this play Hüsken W., “'Van Incommen en begheert men Scat noch Goet': Cornelis Everaert and the Rosary”, in Gosman M. - Walthaus R. (eds.), European Theatre 1470-160o. Traditions and Transformations, Mediaevalia Groningana 18 (Groningen: 1996) 119-129, here 122-123 (on devotion to the rosary in Bruges).

$20 \quad$ Hüsken, Spelen II, 787; Dumolyn J. - Haemers J., "'Let each man carry on with his trade and remain silent'. Middle-class ideology in the urban literature of the late medieval Low Countries", Cultural and Social History 10 (2013) 169-189, here 175.

21 About the materials of the beads and their characteristics, see Ritz G., "Der Rosenkranz", in 50o Jahre Rosenkranz (Cologne: 1975) 51-101, here 74, 88, 100; Kramer B., "Verbondenheid verbeeld. Over de uitbeelding van een rozenkranssnoer op een schilderij van de Meester van Sint-Goedele", Ons Geestelijk Erf 82 (2011) 136-159, here 153-156; King R., “"The Beads with Which We Pray Are Made from It': Devotional Ambers in Early Modern Italy”, in De BoerW.-Göttler C. (eds.), Religion and the Senses in Early Modern Europe, Intersections: Interdisciplinary Studies in Early Modern Culture 26 (2012) (Leiden - Boston: 2013) 153175, here 168-174 (on the tactile and olfactory characteristics of amber).

\section{For use by the Author only | (C) 2015 Koninklijke Brill NV}


of the rosary implied. During the late Middle Ages, and still in the sixteenth century, praying the rosary meant more than just reading — aloud, murmuring or silent-Hail Marys and Our Fathers, or the Latin versions of these prayers. It also involved the meditation through visualization of scenes from the life of Mary and Christ. The cult of the rosary was instituted to supplement the public celebration of Mass and the observance of the Hours. Rosary confraternities stimulated lay association and private devotion in its honour.

The rosary itself became the instrument or practical attribute that helped the individual believer to perform a series of mental, particularly imaginative operations that were learned and became more or less embodied through the reading of a variety of treatises, many of them illustrated. They started to appear in the late decades of the fifteenth century and continued to be printed in the sixteenth. ${ }^{22}$ This period could be considered the heyday of the rosary. ${ }^{23}$ Sales went up after several popes granted indulgences for saying the prayer. ${ }^{24}$ They became popular gifts, too, with many people owning more than one. ${ }^{25}$ The partly overlapping scenes from the life of Mary and Christ were divided over the five decades or series of ten beads a normal rosary consisted of. So every decade was devoted to another scene to be meditated upon during the prayer of ten Hail Marys. Sometimes additional prayers referring to that particular scene were said after each decade.

The praying of a full rosary involved fifteen decades; that is, three times the length of a normal prayer bead. Consequently fifteen scenes were contemplated during the praying of a full cycle. ${ }^{26}$ This number links the rosary to another devotion, namely the joys and sorrows of Mary, usually divided into a series of seven or fifteen uplifting or agonizing moments of her life. ${ }^{27}$ This devotion, too, was stimulated by booklets describing and depicting the scenes involved, providing texts for prayer and meditation. The sorrows of Mary involved many scenes from the Passion, ${ }^{28}$ among them the seven blood-sheddings, the moments in Christ's life when blood had dripped from his bodythe topic of another of Everaert's table plays, to be discussed in a moment.

\footnotetext{
22 Winston-Allen A., Stories of the Rose. The Making of the Rosary in the Middle Ages (University Park, PA: 1997) 25-26.

23 Ritz, "Der Rosenkranz" 94.

24 Winston-Allen, Stories of the Rose 28, 140.

25 Ritz, "Der Rosenkranz" 94-95.

26 Ritz, "Der Rosenkranz" 65.

27 Schuler C.M., "The Seven Sorrows of the Virgin: Popular Culture and the Cultic Imagery in Pre-Reformation Europe, Simiolus 21 (1992) 5-29, here 18, 23-24.

28 Schulten W., "Das Rosenkranzgebet", in 5oo Jahre Rosenkranz (Cologne: 1975) 122-127, here 122; Kramer "Verbondenheid verbeeld" 146-153.
} 
More than just the instrument or practical attribute of the prayer to and meditation on the lives and sufferings of Mary and Christ, ${ }^{29}$ depictions of the rosary in paintings and prints became the graphic symbol or sign for the actual performance of these prayers and meditations. So, when we see a lay donor in an altarpiece or a layman or laywoman in a single portrait holding a rosary, we may assume the portrayed person to be praying - again aloud, murmuring or silently - and to have scenes from the Passion before their real eye, as in the case of an altarpiece, ${ }^{30}$ or before their mind's eye, as in the case of a single portrait. Especially these individual portraits-showing well-to-do city-dwellers in three-quarter view, who are looking or staring into the distance while inconspicuously handling a rosary, hardly noticeable between their fingers, ${ }^{31}$ and half disappearing behind the lower picture frame-suggest they have Mary and Christ on their mind. It is particularly in male portraits that we discern not only a unostentatious use of rosaries, but rosaries that are themselves unostentatious. One sixteenth-century portrait from the Low Countries, a copy after Jan Cornelisz. Vermeyen (c. 1504-1559), dated 1545, may serve as an example [Fig. 6.1]. Vermeyen and his contemporaries portrayed many well-to-do city dwellers, who, although presented as men of the world, through rosaries demonstrated their religiosity. The specimens involved always concern simple, short loops with relatively large beads, or linear strings, counting a limited number of beads, maybe even one-decade specimens, so-called tenners. These were favoured by men. ${ }^{32}$ They might not even have a cross at the end, only a tassel, such as the one carried by the sitter in the aforementioned portrait or hanging on the wall at the back of The Arnolfini Portrait by Jan van Eyck [Fig. 6.2]. This unostentatiousness, as regards both the object and its handling, suggests that these men were praying and meditating while going about their daily affairs.

It is important to mention that in Everaert's play the gift is not shown and presented until two-thirds into the dialogue - that is after two hundred of a total of three hundred lines. Before that, the kind and value of the gift is only hinted at, whereby the case or casket is shown, certainly, but its lid is kept closed.

29 Schulten, "Das Rosenkranzgebet" 124; Winston-Allen, Stories of the Rose 16, 26.

30 See for a discussion of such altarpieces and other devotional images, Kramer, "Verbondenheid verbeeld" 137-144. On image and sensory experience in general, see Harbison C., "Visions and Meditations in Early Flemish Painting", Simiolus 15 (1985) 87-118; Williamson B., "Sensory Experience in Medieval Devotion", Speculum 88 (2013) 1-43.

31 Ritz, "Der Rosenkranz" 91.

32 Ritz, "Der Rosenkranz" 65, 69, 72; Winston-Allen, Stories of the Rose 112; Kramer, "Verbondenheid verbeeld" 153; King, "The Beads" 160. 


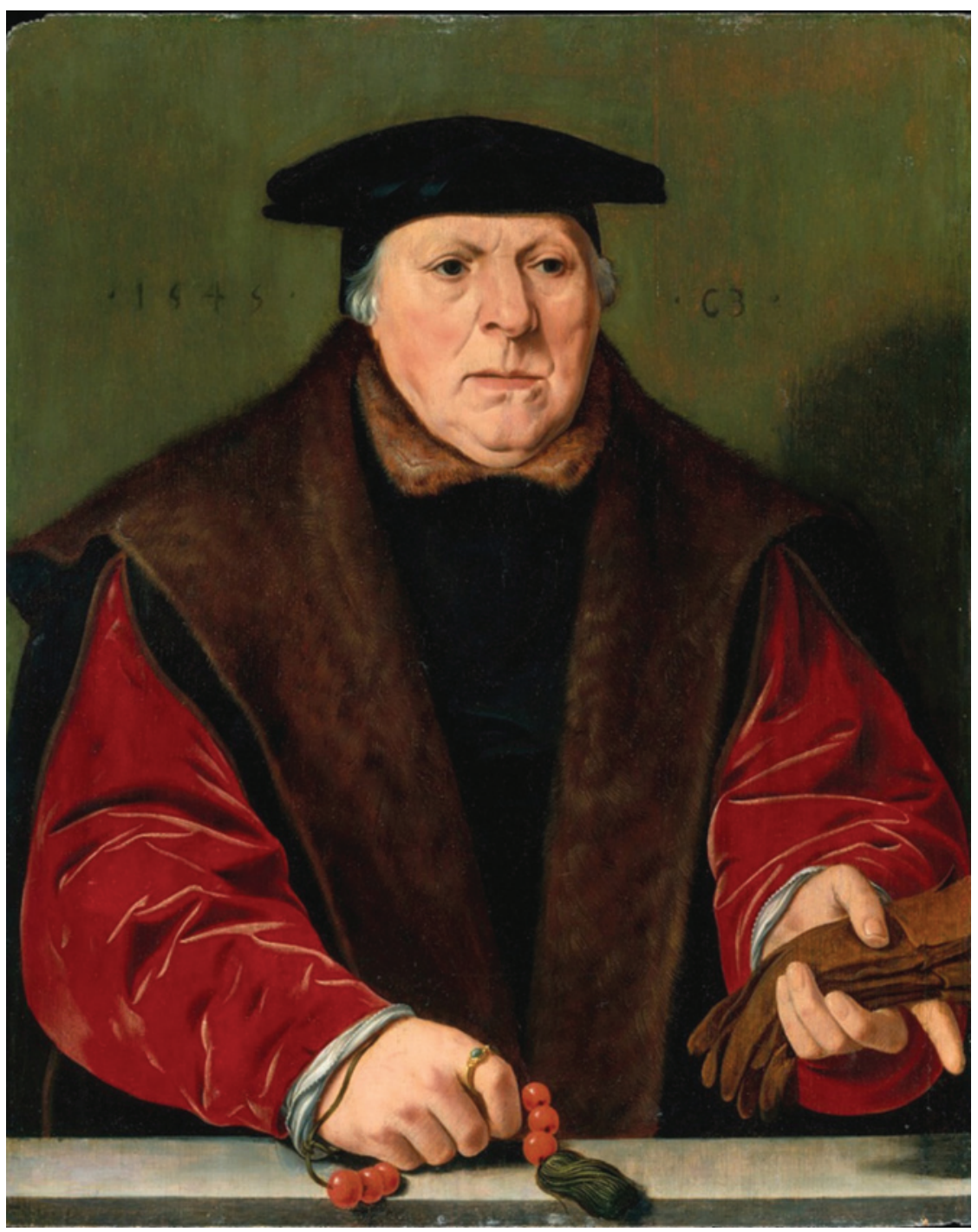

Figure 6.1 Copy after Jan Cornelisz. Vermeyen, Portrait of a Man with a Rosary (1545). Oil on wood, $50.8 \times 41.3 \mathrm{~cm}$. New York, The Metropolitan Museum of Art, The Jack and Belle Linsky Collection, 1982. Image (C) The Metropolitan Museum of Art.

The character that holds it is called Reason (Redene). According to a stage direction she is dressed like 'an eminent lady' ('een houde matroone'; after v. 56). Two characters appear at her side: Sensuality (Zinnelicheyt), meaning the senses, and Willpower (Wille). The sex of the first is not indicated, but it is

For use by the Author only | (C) 2015 Koninklijke Brill NV 


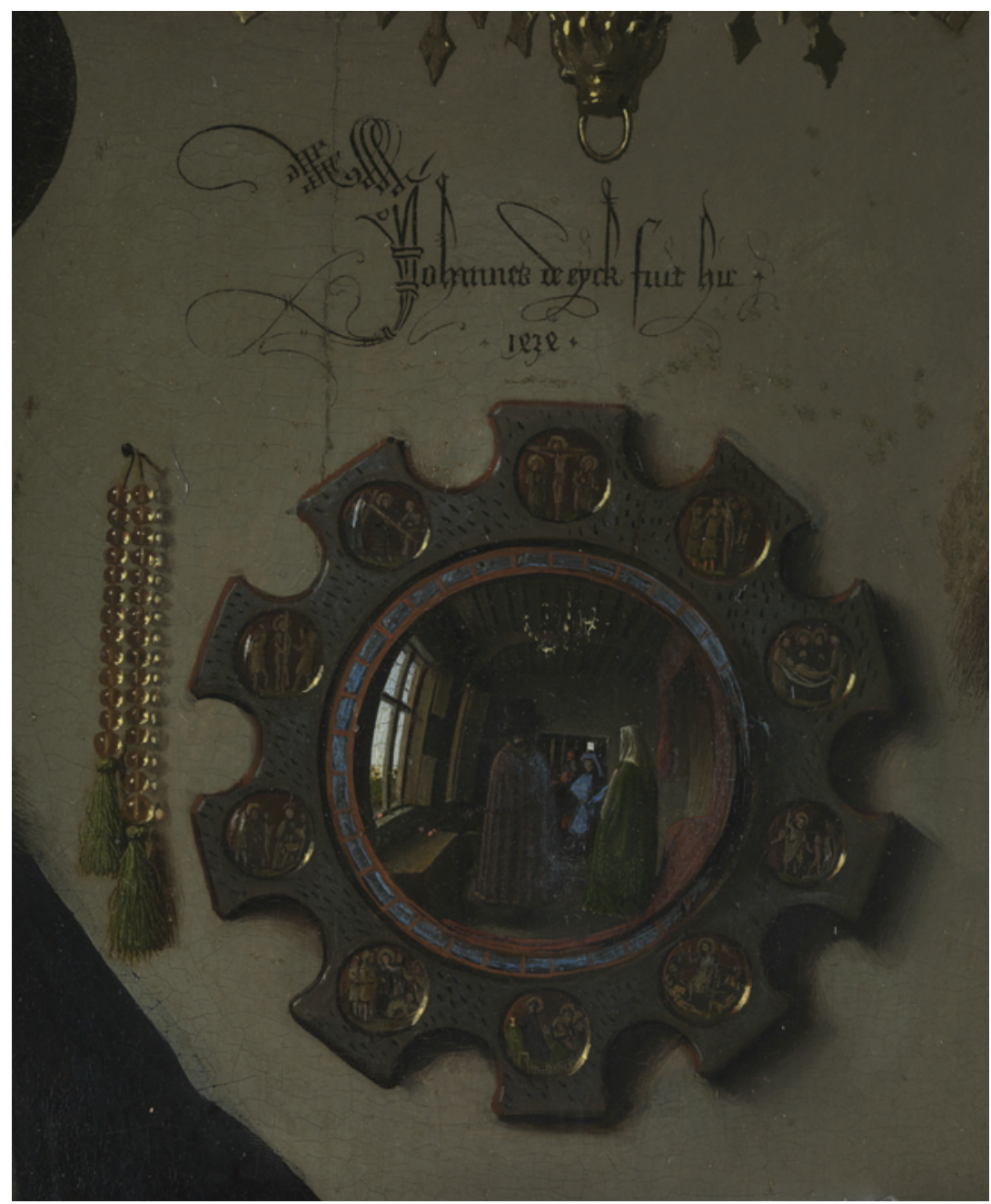

FIGURe 6.2 Jan van Eyck, The Arnolfini Portrait (1434). Oil on oak, $82.2 \times 60 \mathrm{~cm}$. London, The National Gallery. Detail of mirror and rosary. Image (C) The National Gallery.

probably a man. The second is referred to as female. ${ }^{33}$ Table plays are not only short, they count no more than two or three characters on average. The latter two enter the playing area first, one shortly after the other, the playing area being the hall where the company meets, before or between the dinner tables. 
They, too, carry gifts for the king. These are-appropriately-two hats, again with allegorical names. One hat is called Temporary Novelty (Tydelicke Nyeuwicheyt), the other Anticipative Discretion (Voorsieneghe Disscrecie). Temporary Novelty is Sensuality's gift, while Anticipative Discretion comes from Willpower. The choice of a rosary as a gift is appropriate as well, for the Middle Dutch word for chaplet, hoedeken, literally means 'little hat'. The modern Dutch word hoedje may still refer to the coronet, crown or garland of roses by which the rosary is allegorically described and represented. ${ }^{34}$ Additionally the rosary that Reason eventually presents to the king has a symbolic name: Fiery Devotion (Vierighe Devocie).

Through the application of allegorical characters and objects, body and matter are charged with symbolic meaning, or, conversely: through the acts these characters perform with these objects they enable the unseen or unperceivable to become accessible to the audience, to be experienced, understood and remembered by them. However sober its dramaturgy, however light-footed and comic at times the language of its characters, and however straightforward the message it wants to convey, still the play is quite sophisticated in the way it represents the mental operations involved in living a virtuous life. The three characters represent three parts of the soul: reason, willpower and sensuous appetite. These parts sometimes clash, as they more or less do in this play, be it in the light and playful manner appropriate to the festive occasion. A person may crave or have an appetite for something - Sensuality speaks of herself and is described by Willpower as being prone to the sins of the eyes-yet resist that craving with willpower. ${ }^{35} \mathrm{~A}$ justly acting soul requires the highest part, reason, to control the lowest part, appetite, with the help of willpower. All three are presented in this play as indispensable for the good acts of man, in this case the good functioning of the king of the milliners' guild, who, as we are about to see, is a man of the world - such as the man in the portrait after Vermeyen [Fig. 6.1]. Reason is the last to enter the playing area and more or less settles the dispute between Sensuality and Willpower about the need for the senses to be curbed. Her opening line actually entails a popular saying: 'Reason serves all play' ('Redene tot allen spele dient'; v. 57). In other words, man should act with discretion in all circumstances. ${ }^{36}$ 


\section{Hats}

The gifts- the hats-through their name and content reflect the relationship between the characters that present them. Temporary Novelty forms the basis for trade and prosperity, according to the text. The millinery industry, like any other trade, is reigned by fashion. For what else does fashion mean than 'temporary novelty', desired by man through the senses? He who creates such temporary novelty (and for that purpose one has to use the senses, and thus be sensual) will be assured mercantile success. With that message Sensuality hands his hat to the king. Next, Willpower's gift has a mitigating effect on that of Sensuality. After all, it is the task of willpower to direct and control the senses. The two of them express their mutual relationship explicitly: Willpower describes Sensuality as someone whose conduct is determined by outward appearances, who is driven by curiosity, has a craving for enjoyment and is prone to envy. ${ }^{37}$ Sensuality retorts that it is the will- the free will, of course - that stimulates man to either an unbridled or a cautious use of his senses. ${ }^{38}$ Willpower's gift exemplifies this controlling function: Anticipative Discretion is the ability to avoid adversity, mitigate suffering and increase patience - truly a fine quality in a real king. ${ }^{39} \mathrm{~A}$ tradesman, too, may benefit from it: it reduces losses and increases profits. In physical terms the hat may protect him from wind, rain and sun — an indispensable piece of clothing for a travelling businessman, one would think. Before presenting him with the hat, Willpower allows Sensuality to put it on. That, according to the text, the latter either does wrong, or the hat does not fit or suit him. In either case it is clear that sensuality and discretion are difficult to reconcile. At the end of the verbal exchange this second gift is presented to the guild's king as well. It should literally cover his will, Reason concludes.

In order to impress the allegorical meaning of both hats on the audience, their names, particularly the central nouns nyeuwicheyt ('novelty') and disscrecie ('discretion'), are repeated over and over again. The same happens in the part of the play_-much longer than the previous ones—-devoted to the gift by Reason; that is, the rosary called Fiery Devotion. As soon as she has revealed its name, she starts repeating it, both the whole name, the word devocie ('devotion'), and the word hoedeken, thus clearly establishing the link among the object and its use, which must have immediately or gradually triggered the

\footnotetext{
$37 \quad$ Vv. 19-42.

$38 \quad$ Vv. $43^{-56 .}$

39 Vv. 111-165.
} 
correct identification of the 'little hat' among the audience, an identification Sensuality and Willpower fail to make - a clear example of dramatic irony.

This 'little hat', thus Reason starts her enigmatic explanation, is sweet, virtuous and valuable, hinting, of course, at the spiritual meaning of the expressions used.$^{40}$ Its virtuousness can hardly be described. It leads Willpower to suppose that it is produced abroad, and Sensuality to guess that it contains precious stones. Both are wrong, according to Reason. In that case, Willpower retorts, it cannot be a hat that one can wear on his head or carry in his hand or on his belt. But indeed one can, says Reason. If he is talking about a real hat that is neither foreign nor beset with jewels, how, then, can it be more valuable than the one presented by Willpower, Sensuality wants to know. Because, says Reason, its value lies in its virtue. When carried inside-in the heart-it has the power to cast away all foes. When Reason then refers to his present as a hoedekin van minnen ('little hat of love'; v. 190), Willpower suspects he means a garland of flowers, of roses or daisies, such as a lover would present to his beloved; a token, that is, of worldly instead of spiritual love, thus unknowingly getting closer to the truth.

When Reason brings out the casket but still does not open it, Sensuality in particular reveals his surprise: such a small box cannot contain a real hat! Reason continues to describe the gift: it is worthier of praise than anything in the world. Then it must be embedded with gems and pearls, Sensuality proposes. Willpower says to Reason: you speak in parabelen ('parables'; v. 208) and tries to get closer to the truth by asking who manufactured the chaplet. Its religious meaning now gradually emerges. It was made, says Reason, by a powerful king (he means God or Christ) who sent it to a particular maiden (Mary, of course) out of love. Sensuality now threatens to become angry if Reason does not immediately disclose the name of his gift. Reason gives in: it is called Fiery Devotion, ${ }^{41}$ the kind of devotion that every king, like every human being, should show to God. Through its name the rosary is explicitly linked to its spiritual use, that is, fiery devotion. Willpower asks what kind of hat that is. Reason's answers become even more cryptic now: in honour of the maiden who received this hat, he says, we should present to her that same hat (he means the prayer), which was created by her fiery devotion. Sensuality can no longer wait and demands to see it, to let it be shown. Then Reason opens the casket and shows its content: this precious jewel, she says, worth more than any hat, brought from heaven.

Willpower finally mentions its real name, its source and destination, its maker, bringer and receiver: Mary's hat, brought from heaven to Nazareth as

$\begin{array}{ll}40 & \text { Vv. } 166-169 . \\ 41 & \text { V. } 216 .\end{array}$


a salutation from the Trinity. The three of them extemporize on the rosary's spiritual meaning, most poignantly described by Reason as a hat to be worn internally, in one's memory, with fiery devotion. Then he presents the casket with the rosary to the king, calling it a diadem stemming from fiery devotion, which makes the soul glorious before God's eyes. He should praise Mary with it every day. There is no sweeter devotion than to 'read' this hat. Reason sets up the conclusion by calling upon the king to keep and preserve all three presents internally, after which all three characters repeat their own names, those of their gifts and their meaning for him who receives them. ${ }^{42}$

\section{Platter, Spices and Comfit}

The second table play to be discussed is the Play on the Seven Blood-Sheddings (Esbatement van de Zeven Bloetsturtinghen), ${ }^{43}$ also dated 1530, written for the installation of the king of an unknown Bruges guild. ${ }^{44}$ It is about as long as the previous one: a little over 300 lines. In this play, however, the gift is already revealed-actually, it is being carried into the assembly room-after only 73 lines. The remaining text is used to interpret its meaning. That is done by two characters: a man, Joyous Will (Blyden Wille), and a woman, Happy Deed (Jonsteghe Daet).45 The complexity of this table play lies not in the relation between the concepts indicated by their names. They are alluded to by the characters in a straightforward manner: the will precedes the deed, and one cannot work without the other. ${ }^{46}$ Only towards the end of the play are their names loosely associated with the presented gifts, in the sense that these names add to the gifts' potential and actual effects.

What these gifts are seems evident at first but becomes more complicated once the two characters start to describe them. They play a role in a multilayered exposition of the meaning of Christ's blood-sheddings. The following moments from his life and suffering are mentioned: the circumcision, the sweating of blood in the Garden of Gethsemane, the flagellation, the coronation with thorns, the ripping off of his clothes, thus tearing open his wounds, the stretching of his body on the cross and the following crucifixion and, finally, the piercing of his side by Longinus. This devotional topic, too, must

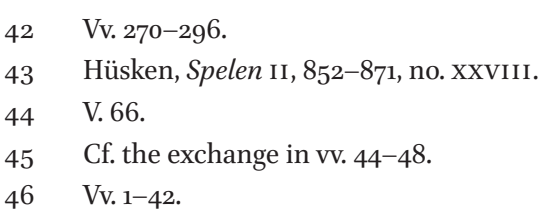


have been informed by Everaert's religious reading and must have appealed to his audience.

One of the gifts is identified by Joyous Will as a platter or dish, probably in majolica, the edge of which is decorated with what he describes as vaenkens ofte bannyeren ('flags or banners'; v. 76). He is likely referring to a pattern of triangle-shaped banners, as can be seen on a dish in the Robert Lehman Collection in The Metropolitan Museum of Art [Fig. 6.3]. Initially, though, it seems that the decorated platter is not the gift, but rather a collection of seven exotic spices, contained in pots or jars: namely zedoary, ginger, pepper, spikenard, cinnamon, clove and cardamom. As in the previous play, their meaning or value is explained predominantly in medicinal terms, and is connected directly to the receiver, the king of the guild. He is someone who, as Happy Deed explains, regularly travels to faraway places. ${ }^{47}$ The spices, says Joyous Will, will strengthen his body, comfort his soul and protect him from pain. ${ }^{48} \mathrm{In}$ the Middle Ages, 'spices were luxurious, exotic, foreign, and expensive. ${ }^{49}$ They could only be imported at considerable cost and became items of conspicuous consumption, which the well-to-do liked to use in various dishes..$^{50}$ Their high price and distant origin - close to Paradise; some even, such as spikenard, were mentioned in the Bible-enhanced their reputation in both medicine and religion, and this depended for a great deal on their flavour and aromatic characteristics. $^{51}$

Instead of starting to name and explain the meaning of each of the spices, Happy Deed begins by mentioning the Sweet Name of Jesus, ${ }^{52}$ a popular late medieval devotion, ${ }^{53}$ more or less presenting the name as the first spice because of its sweetness. Although nothing in the text indicates this, it seems likely that he simultaneously points at what may have been an IHS monogram

\footnotetext{
$47 \quad$ V. 85

48 Vv. 89-90, 92-94.

49 Freedman P., Out of the East. Spices and the Medieval Imagination (New Haven - London: 2008) 39. Also see Winter J.M. van, Spices and Comfits. Collected Papers on Medieval Food (Blackawton, Totnes: 2007) 94, 131, 141.

50 Freedman, Out of the East 6, 19-24, 42. On the concept of conspicuous consumption generally, see Veblen T., The theory of the leisure class. An economic study of institutions (New York: 1961 [1934]).

$5^{1}$ Freedman, Out of the East 13-18, 52-55, 76-78, 81-82. On the spiritual meanings of fragrances and flavours, also see Falkenburg R.L., The Fruit of Devotion. Mysticism and the imagery of love in Flemish paintings of the Virgin and Child, 1450-1550 (Amsterdam Philadelphia: 1994) passim.

$5^{2}$ V. 95. It is again referred to towards the end of the play (v. 305).

53 For its establishment in England, see Pfaff R.W., New Liturgical Feasts in Later Medieval England (Oxford: 1970) 62-83.
} 


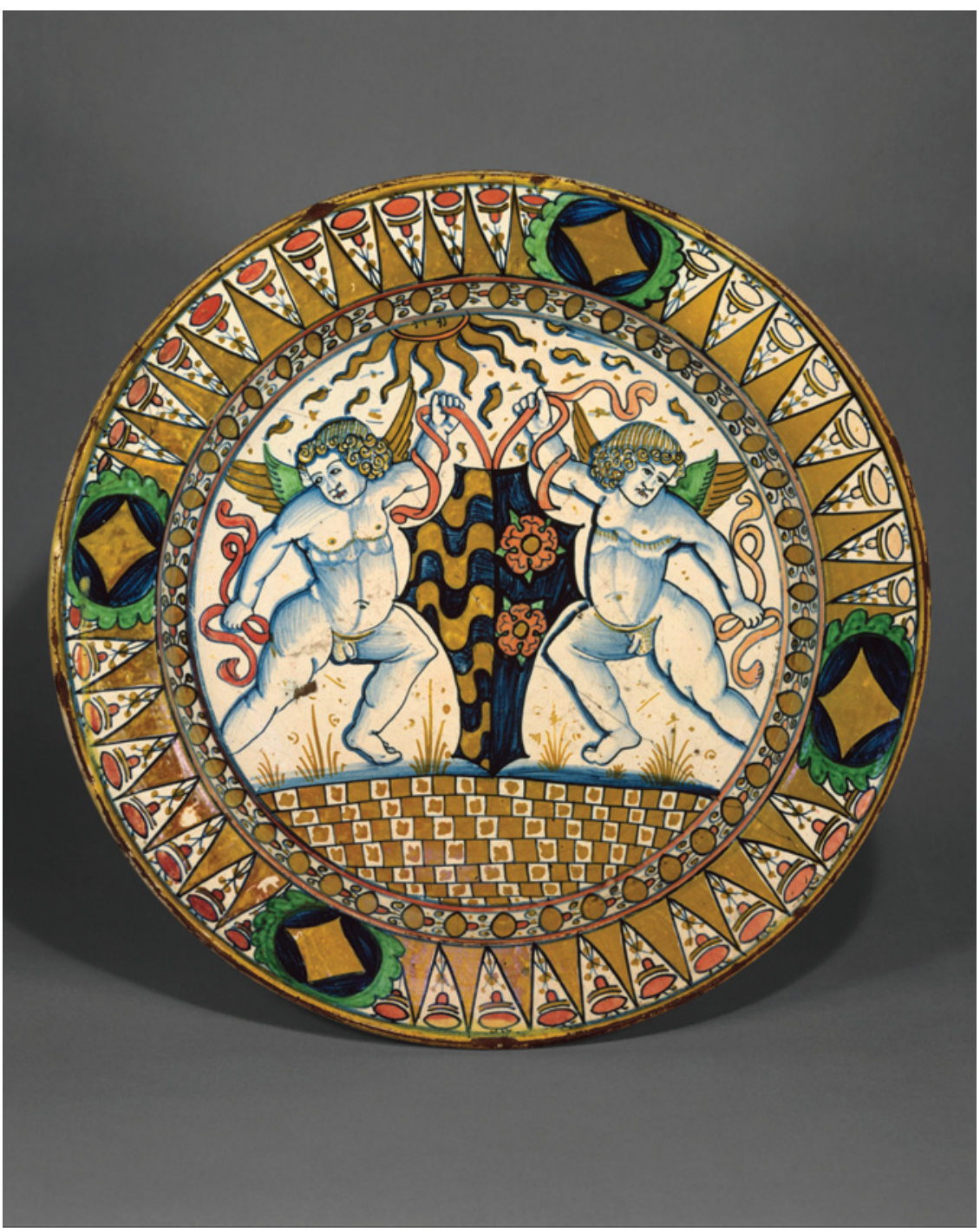

FIGURE 6.3 Disk (c.1510). Majolica, diameter $43.5 \mathrm{~cm}$. New York, Metropolitan Museum of Art, Robert Lehman Collection, 1975. Image (c) The Metropolitan Museum of Art.

or other abbreviation of Christ's name and symbol of the devotion to his Sweet Name, painted on the platter. Many examples of such platters have survived, such as another dish in the Robert Lehman Collection [Fig. 6.4]. ${ }^{54}$ Next Happy Deed mentions seven liquid sweets that dripped from his body, seven

54 On depictions of majolica pottery in early Netherlandish painting, including examples carrying the IHs monogram, see Jékely Z., "Majolica Jugs in late Medieval Painting", in

For use by the Author only | (C) 2015 Koninklijke Brill NV 


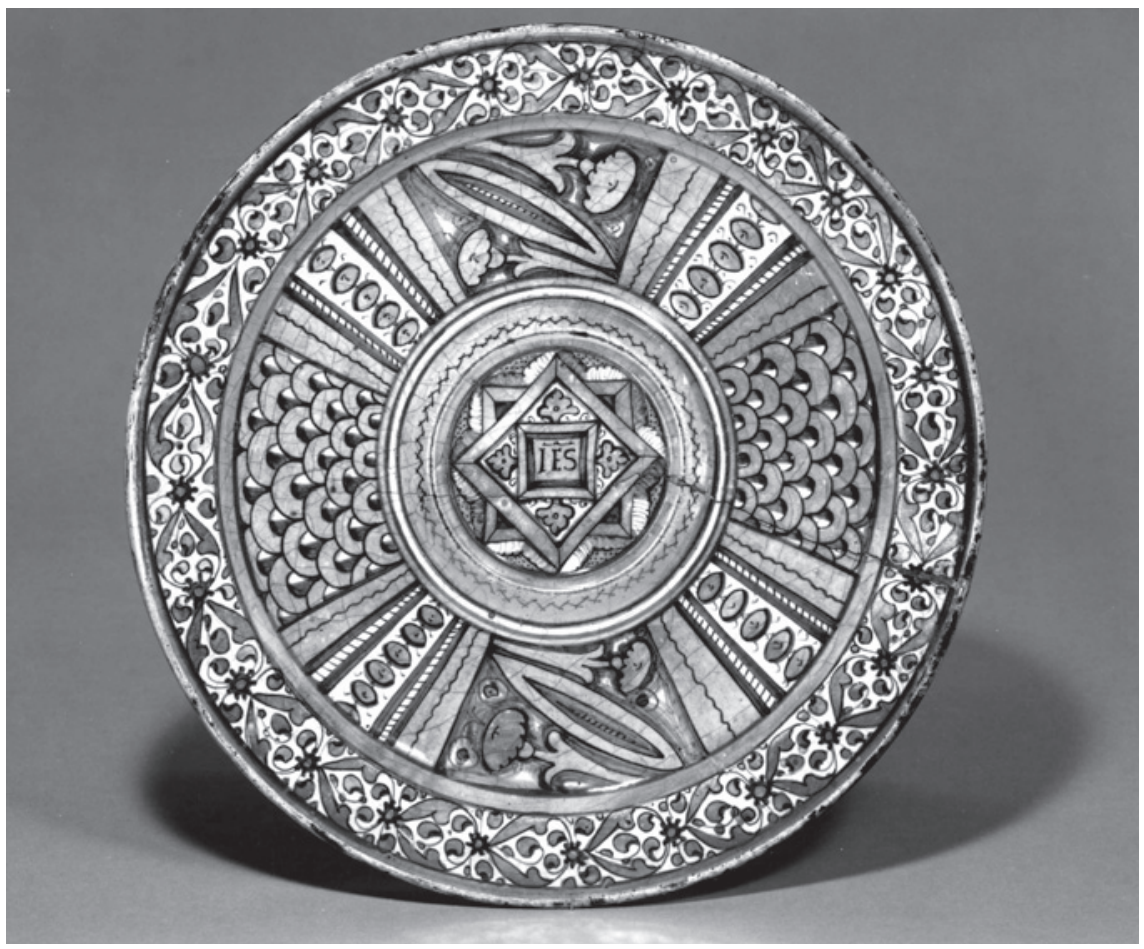

FIGURE 6.4 Dish for a ewer (c. 1530-1540). Majolica, diameter $32.7 \mathrm{~cm}$, New York, The Metropolitan Museum of Art, Robert Lehman Collection, 1975. Image (C) The Metropolitan Museum of Art.

sweets displeasing to Satan. Then they hint that these are related to the seven blood-sheddings. They are described as pardon, forgiveness, grace, peace, concord, remission of sin and the opening of heaven. ${ }^{55}$ The sweets refer to (or are referred to by) what Joyous Will describes as de zevenderhande tregye ('the seven layer comfit'; v. 103) consisting of several fruits, nuts and spices: oranges, pineapple seeds, hazelnuts, ginger, coriander and cinnamon. ${ }^{56}$ Being a dessert, ${ }^{57}$ it was probably presented towards the end of the banquet. Like

Balla G. - Jékely Z. (eds.), The Dowry of Beatrice -Italian Majolica Art and the Court of King Matthias (Budapest: 2008) 55-66.

55 Vv. 100-102.

$5^{6}$ Fruit was rarely eaten raw, but usually dried or sugared or made into comfits, adding nuts and spices. Freedman, Out of the East 41. On comfits and their place in medieval cuisine, see Van Winter, Spices and Comfits 242, 346, 350-352.

57 Van Winter, Spices and Comfits 299.

For use by the Author only | (c) 2015 Koninklijke Brill NV 
the fluid sweets dripping from Christ's body, they drive out 'de smaecke der bitterheyt ende corruptien' ('the taste of bitterness and corruption'; v. 108). ${ }^{58}$ Is it possible that not only the seven spices but also this comfit was presented on the platter with the IHS monogram or a comparable acronym? The analogy between comfit and Christ not only illustrates the application of the metaphor of food consumption to the process of mystical unification, ${ }^{59}$ but also says something about the high social value attributed to the particular kind of food involved in the comparison. Being able to afford and eat such fine comfitsfine enough to be compared to the body of Christ—contributed to the guild's prestige and unity, ${ }^{60}$ as did gift-giving and, for that matter, banqueting in general. ${ }^{61}$ The comfit with its differently-coloured ingredients possibly presented a visual attraction, too, thus adding to the comparison's appeal. ${ }^{62}$

Its sweetness refers to Jesus, says Happy Deed, who is brought to the king 'in figuere' (v. 110), which can mean two things: figuratively, that is by means of figurative speech, or by means of material illustration, using real images, either two-dimensional, in paint or print, or three-dimensional, in the form of living images (tableaux vivants) or plays. ${ }^{63}$ It turns out that Joyous Will and Happy Deed do both: they use figurative speech in addition to material illustration, to which they add the pots with exotic spices. It is their intention to compare Christ's seven blood-sheddings with these seven spices. Whereas the latter preserve the body, the former preserve the soul. ${ }^{64}$

$5^{8}$ On the spiritual associations of sweet and bitter smells and tastes in relation to consumption, see Falkenburg, The Fruit of Devotion 12, 6o, 66.

59 Falkenburg, The Fruit of Devotion ${ }_{56}^{6-76}$ (chapter 3 ).

6o Scholliers P., "Meals, food narratives, and sentiments of belonging in past and present", in Scholliers P. (ed.), Food, drink and identity. Cooking, eating and drinking in Europe since the Middle Ages (Oxford \& New York: 2001) 3-22, here 10-11; Tomasik T.J. - Vitullo J.M., "At the table. Metaphorical and material cultures of food in medieval and early modern Europe", in Tomasik T.J. - Vitullo J.M. (eds.), At the table. Metaphorical and material cultures of food in medieval and early modern Europe (Turnhout: 2007) XI-Xx, here XV-XVI.

61 Dumolyn - Haemers, "'Let each man' " $175^{-176 . ~ O n ~ g i f t-e x c h a n g e ~ i n ~ g e n e r a l, ~ s e e ~ T h o e n ~ I ., ~}$ Strategic Affection? Gift Exchange in Seventeenth-century Holland (Amsterdam 2007) 18-20.

62 On the sensual aspects of food and their link with Eucharistic devotion, see Bynum C.W., Holy Feast and Holy Fast. The Religious Significance of Food to Medieval Women (Berkeley Los Angeles: 1987) 60.

63 Ehrstine G., "Framing the Passion: mansion staging as visual mnemonic", in Gertsman, Visualizing Medieval Performance 263-277, here 63-65. Also see Ehrstine G., "Passion Spectatorship between Private and Public Devotion”, in Gertsman E. - Stevenson J. (eds.), Thresholds of Medieval Visual Culture: Liminal Spaces (Woodbridge: 2012) 302-320.

64 Vv. 114, 117. 
How exactly the sufferings of Christ were presented remains unclear. Joyous Will explicitly says that the comparison 'will appear before the eye' ('voor ooghen mach blycken'; v. 115). Were the scenes painted on the edge of the platter, like on the frame of the convex mirror in The Arnolfini Portrait [Fig. 6.2]? Or did the characters show a series of woodcuts to the audience depicting the seven blood-sheddings? Or were these scenes mimed by actors? The last option certainly would have made the staging of this table play a much more ambitious and costlier affair. On closer inspection the blood-shedding must have been visualized in some way. It would be illogical not to materially represent the thing to be compared (the comparans) and to only show one of the elements it was being compared with (the comparandum). If the spices had been the only visual objects in the comparison, it would have made more sense mnemotechnically to describe them first. Moreover, at the fifth stage of each cluster, when the presenters directly address the king, they sometimes use words that suggest that the sufferings of Christ were indeed not only aurally but also visually perceived. Thus, he is instructed to 'see' ('siet'; vv. 155) or 'notice' ('merct'; v. 181) the actions performed by or directed towards Christ. After the seventh and last cluster he is asked to 'impress them' (prentse'; v. 288) on his heart, and to 'lock' (sluut'; v. 301) Jesus's Passion there, as if it were a treasure vault. Even if the life of Christ was only referred to in words, the performance-due to the broad familiarity of contemporary lay audiences with illustrated descriptions of the joys, sorrows and sufferings of Mary or Christ, varying in number-would have stimulated these scenes to appear before the inner eye of the audience, a process prompted by the systematic set-up of the sevenfold comparison and the fact that at the end of each of them Joyous Will and Happy Deed imperatively call upon the king to take its content at heart, to follow Christ's example and not to fall into the deadly sin associated with the taste or effect of the given spice.

\section{A Print or a Charm}

Thus, the play is very much like a devotional treatise acted out on stage. In fact, the figurative demonstration follows a fourfold scheme in which, first, a bloodshedding is presented; which then is connected to a particular spice, its taste (in three cases) and medicinal effect (in six cases); after which this sensual experience is associated with one of the seven cardinal sins; and, finally, with one or more Old Testament characters who committed that sin. ${ }^{65}$ Properly

65 Vv. 119-288. In the following each blood-shedding is followed by a spice, its taste (if mentioned; otherwise a dash is used) and medicinal effect (if mentioned; otherwise a

\section{For use by the Author only | (C) 2015 Koninklijke Brill NV}


speaking, there even is a fifth level of explanation, namely that of the moral admonitions to the king. Whereas the spices are recommended as natural cures against bodily injury, the blood-sheddings are praised as a spiritual remedy or medicine against the temptation of $\sin .{ }^{66}$ Ultimately the gifts are presented to the king while Joyous Will and Happy Deed pronounce an eight-line rondel. ${ }^{67}$ (They also may themselves be the presenters.) Because of the fact that in this rondel the king is explicitly called upon in three repeated lines to receive the blood-sheddings_-'Accept [it]' ('Neimpt'; vv. 297, 300, 303) ${ }^{68}$ —it is hard to imagine that they were not presented in any material way, as an object of some sort. The first line after the rondel refers to the Name of Jesus again, calling upon the king to receive it in his heart. This way the platter that possibly contained the IHS monogram was included in the gift offering as well.

Two lines down Happy Deed admonishes the king to keep 'this small image' ('dit beildekin'; v. 307) as a memory of those who gave it to him. ${ }^{69}$ The word beildekin may refer to a devotional print, a broadsheet representing Christ in one or more scenes from the Passion or maybe the IHs monogram, again hinting at the devotion to his Holy Name. During the late fifteenth and early sixteenth centuries these kinds of woodcuts combining devotional images and prayers were in high demand, especially those related to popular devotions such as the rosary and the Holy Name of Jesus. ${ }^{70}$ Perhaps the print depicted all seven blood-sheddings. After all, the first of them was seen as the moment of

dash is used), a cardinal sin, and the Old Testament characters who committed that sin: 1) circumcision: zedoary / bitter / for children with threadworms / lust / Reuben, Amnon, Lot, David, Solomon; 2) sweating of blood: ginger / hot and salty / - / gluttony / Haman, Esau, Isaac, Job's children, the Amalekites; 3) flagellation: pepper / - / for the healing of wounds / envy / Rachel, Abimelech, Jacob; 4) crowning with thorns: spikenard / - / for embalming bodies / pride / Adam, Rehoboam, Sennacherib; 5) ripping off of clothes: cinnamon / sweet and dry / medicinal, used in recipes / greed / Achan, Gehazi, Samuel's sons; 6) crucifixion: clove / - / invigorating, strengthens the body / sloth / Elijah, Sisera; 7) piercing of side: cardamom / - / consumes pain, both inside and outside / wrath / Cain, Miriam, Jezebel, Saul.

66 Vv. 290-292, 294-296.

67 Vv. 297-304.

68 The opening and closing lines of the rondel read: 'Neimpt danckelic, heer conync, te desen termyne / den blyden wille met de jonsteghe daet' ('Accept [it], Lord King, at this very moment / both joyous will and happy deed'; vv. 297-298, 303-304), thus linking the blood-sheddings and probably also the spices to the names of the play's two characters in the sense that both in the blood-sheddings and the spices one may discern the aspect of potential or intention (will) and effect or working (deed).

69 Vv. 307-308.

70 Scribner B., "Popular Piety and Modes of Visual Perception in Late-Medieval and Reformation Germany", The Journal of Religious History 15 (1989) 448-469, here 449-456.

\section{For use by the Author only | (C) 2015 Koninklijke Brill NV}


his name-giving, Jewish circumcision being the equivalent of Christian baptism. Both Passion and Holy Name were referred to in the preceding lines. ${ }^{71}$ Or does 'beildekin' refer to a small three-dimensional representation, a statue or a charm in the form of a cross, a crucifix or a medallion with one of the aforementioned subjects on it? In any case it must have been a portable gift, since the final lines suggest the king should take it with him on his journeys: 'Wherever you travel, in villages, in towns, / keep it with you forever' ('Waer ghy reyst, in doorpen, in steden, / houdet eeuwich by hu'; vv. 310-311). ${ }^{72}$ This would mean that he not only received the decorated platter and the set of pots or jars with exotic herbs, but also a small token to carry with or on him, somehow depicting or representing one or more scenes from Christ's life or Passion.

\section{A Book?}

Various devotional books printed in the last quarter of the fifteenth and in the first half of the sixteenth centuries linked contemplation of and prayer to the Virgin to the rosary, or at least the saying of Our Fathers and Hail Marys, either in Latin or the vernacular. Prayers to the Passion, especially to the bloodsheddings, as well as short meditations on their content, usually ended with a rubric indicating that one or more Our Fathers and Hail Marys should be said. In many of these booklets - which all had a practically sized octavo formatthese prayers or meditations were divided among the days of the week, which in the case of the blood-sheddings stimulated the choice for a cycle of seven, as well as the combination with prayers or meditations on a sequence of events that were closely linked to the blood-sheddings: the seven sorrows of the Virgin. Going by the number of editions and extant copies of some of these titles, they must have been widespread and very popular. A rough survey yields at least nine of them. It seems worthwhile to dwell on their structure and content, in order to illustrate how believers, with their help, could in an almost matter-of-fact manner incorporate devotion to (the sufferings of) both Mary and Christ, a kind of devotion heavily imbued with corporeal and performative elements, into their daily lives. Although many of these titles were originally written for (semi-)religious persons, especially women, since in some we find explicit ref-

On the use of such woodcuts generally see Areford D.S., The Viewer and the Printed Image in Late Medieval Europe (Farnham - Burlington, VT: 2010).

71 Vv. 301, 305 .

72 Also see v. 286: 'dach ende nacht, waer ghy ghaet, vaert of ryt' ('day and night, wherever you walk, sail or ride'). 
erences to female readership they must have reached laypeople as well. They fit into a tradition of 'shaping and training of the self though some kind of reading', and helped to create 'forms of identity [that] were anchored by an appeal to inner experience. ${ }^{73}$

One such booklet is Onser lieuer vrouwen croon (Our Blessed Lady's Crown). It consists of a series of 23 benedictions of parts of Mary's body, starting with her head and ending with her feet. Each blessing ends with a rubric indicating an Ave Maria. ${ }^{74}$ The preface advises the blessings to be read on Saturdays especially and on all Marian feasts, and to pray as many Hail Mary's as one likes, kneeling in private before a statue of the Virgin or before an altar devoted to her. ${ }^{75}$ The title of the consulted edition suggests that the work contained two more treatises: Onser liever vrouwen souter (Our Blessed Lady's Psalter) and Onser liever vrouwen mantel (Our Blessed Lady's Mantle). Apparently, the book's printer, Jan Seversz. from Leiden, used to issue all three in one edition, but this time only included the first. ${ }^{76}$ Separate editions of Onser liever vrouwen souter appeared as well. This work, falsely attributed to St Bernard of Clairvaux (a great way, for sure, to increase its popularity), consists of 150 meditations on the Virgin, divided over the week, each separated, again, by an Ave Maria. ${ }^{77}$ The number of meditations made the book comparable to the real Psalter (hence its name), facilitating its use as a lay alternative to the Liturgy of the Hours, and additionally offering the opportunity to pray three rosaries of fifty Ave Maria's, adding a Pater Noster to each decade.

Moreover, praying the rosary in this manner was called 'our Blessed Lady's psalter' in Die costelike scat der geesteliker rijckdoem (The Precious Treasure of Spiritual Richness).$^{78}$ It defines a proper rosary as consisting of five decades, a number corresponding to the length of many sets of medieval prayer beads. It contains, among other things, a list of 55 'articles or points' ('articulen oft punten'), topographical locations related to Christi's life and Passion to be precise, where the reader may imaginatively halt and pray (parts of) the

\footnotetext{
73 Bryan J., Looking Inward. Devotional Reading and the Private Self in Late Medieval England (Philadelphia: 2008) 5 .

74 Leiden, Jan Seversz., after 1513; ex. The Hague, Royal Library, KW 228 G 1 (NK 437).

75 F. A2r.

76 One example of an edition containing all three treatises is: Delft, Christiaen Snellaert, 1490; ex. The Hague, Royal Library, 150 E 18.

77 Leiden, Hugo Jansz. Van Woerden, after 1495; ex. The Hague, Royal Library, KW 227 G 32 [1] (NK 288).

78 Zutphen, Thieman Petersz. Os van Breda, 1518; ex. The Hague, Royal Library, KW 228 G 30 (NK 1806) f. K7v.
} 
rosary. ${ }^{79}$ Cross signs in the right margin apparently have the function of reminding the reader to move on to the next bead [Fig. 6.5]. When the sequence arrives at the Road of the Cross, a rubric says that the points (or stations) are described so lively 'as if those [who halt there imaginatively] were present in Jerusalem themselves' ('oft sy toe Jerusalem selven tseghenwoerdich weren'). ${ }^{80}$ The book is presented as being profitable to 'all Christian people' ('allen Kersten menschen') and includes a description of the origins of the cult of the rosary, referring, among others, to Alanus de Rupe (1428-1475), the cult's fervent advocate and founder of the first confraternity devoted to its propagation. ${ }^{81}$ In fact, the book contains the list of regulations of that confraternity as a ready-to-apply model for any new chapter to be established, including a list of indulgences stimulating the praying of the rosary. ${ }^{82}$ At the end two other confraternities are mentioned that pray the rosary as part of their devotion: that of the seven sorrows and that of the Sweet Name of Jesus. In the latter's case an indulgenced prayer cycle is defined in which each Pater Noster and Ave Maria should be preceded by a prayer to the Sweet Name of Jesus. Its beginning is marked by a woodcut representing the Virgin and Child with St Anne surrounded by a rosary, with five roses separating the decades [Fig. 6.6].

It was also possible to interweave the praying of the rosary with the contemplation of Christ's sufferings, Mary's seven sorrows partly overlapping with these. Another version of Onser liever vrouwen souter, for example, includes a prayer on the rosary consisting of a Pater Noster with ten Ave Marias, each alternating with a short description of a Passion scene ${ }^{83}$ This brings us to late medieval treatises that stimulated devotion to Christ's blood-sheddings. In his introduction to Everaert's play, its editor Wim Hüsken mentions several booklets whose content may have inspired him, or better yet, perhaps: whose content paralleled in print what Everaert tried to achieve on stage. ${ }^{84}$ One option is the Oefeninghen in die seven bloetstortinghen (Exercises on the Seven BloodSheddings) by Godschalc Rosemondt (c. 1480-1526). ${ }^{85}$ It links each of Christ's sufferings to a particular day of the week, a cardinal sin, its opposite and a

\footnotetext{
$79 \quad$ F. Kiv.

80 F. K4r.

81 F. K8v.

82 Onser liever vrouwen souter also includes an indulgence (f. A2r-v).

83 Amsterdam, Doen Pietersz., c. 1520; ex. The Hague, Royal Library, KW 227 G 9 (NK 294) f. $\mathrm{H} 8 \mathrm{v}-\mathrm{Y} 4 \mathrm{r}$.

84 Hüsken, Spelen II, $852-853$.

85 Antwerp, Henrick Eckert van Homberch, 1516; ex. The Hague, Royal Library, KW 229 G 7 (NK 1828).
} 


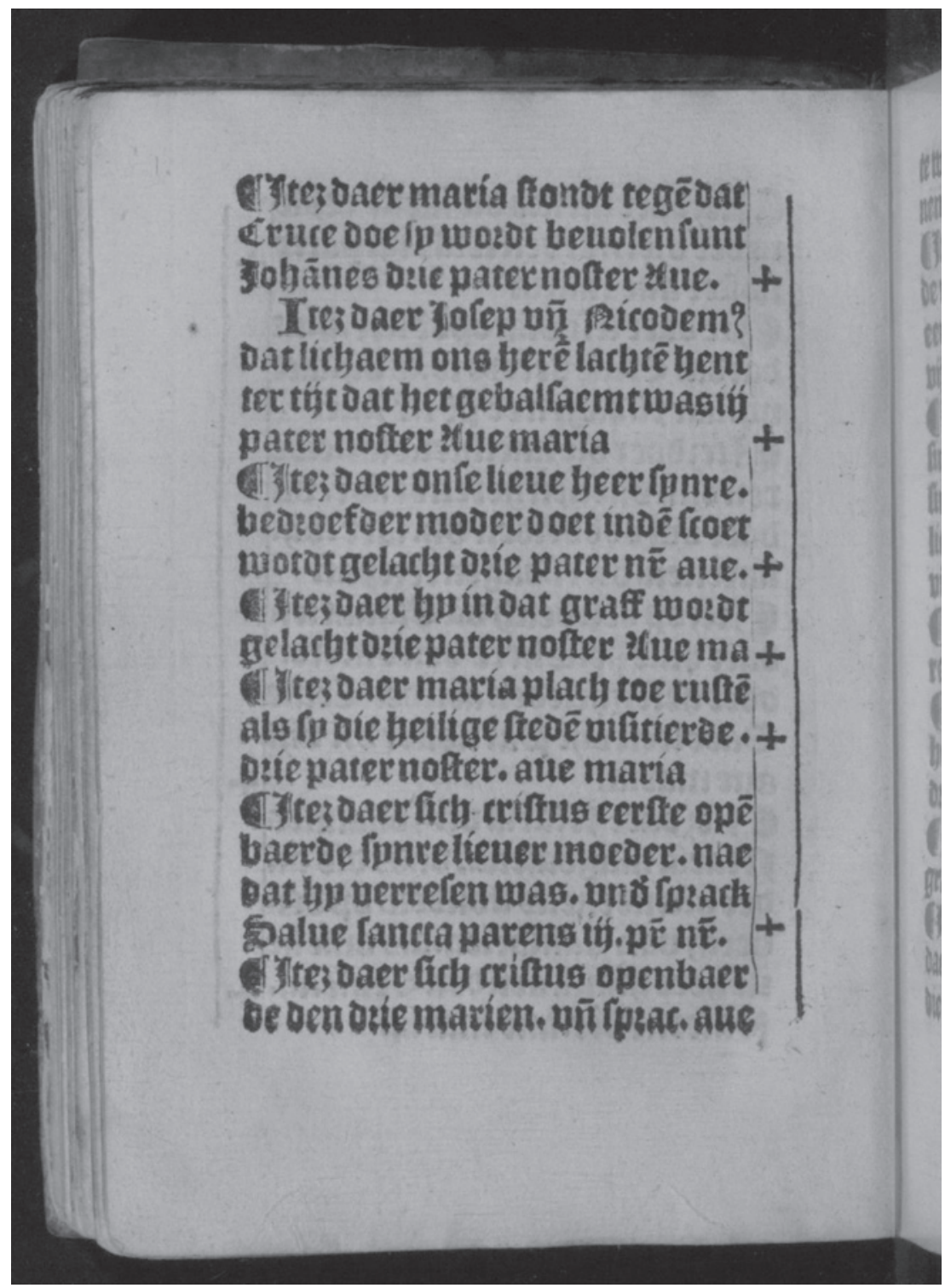

FIGURE 6.5 Fragment of "The fifty-five articles or points of the Passion". Die costelike scat der geesteliker rijckdoem (Zutphen, Thieman Petersz. Os van Breda: 1518), The Hague, Royal Library: KW 228 G 3o, f. K5v. Image (c) ProQuest LLC.

For use by the Author only | (C) 2015 Koninklijke Brill NV 


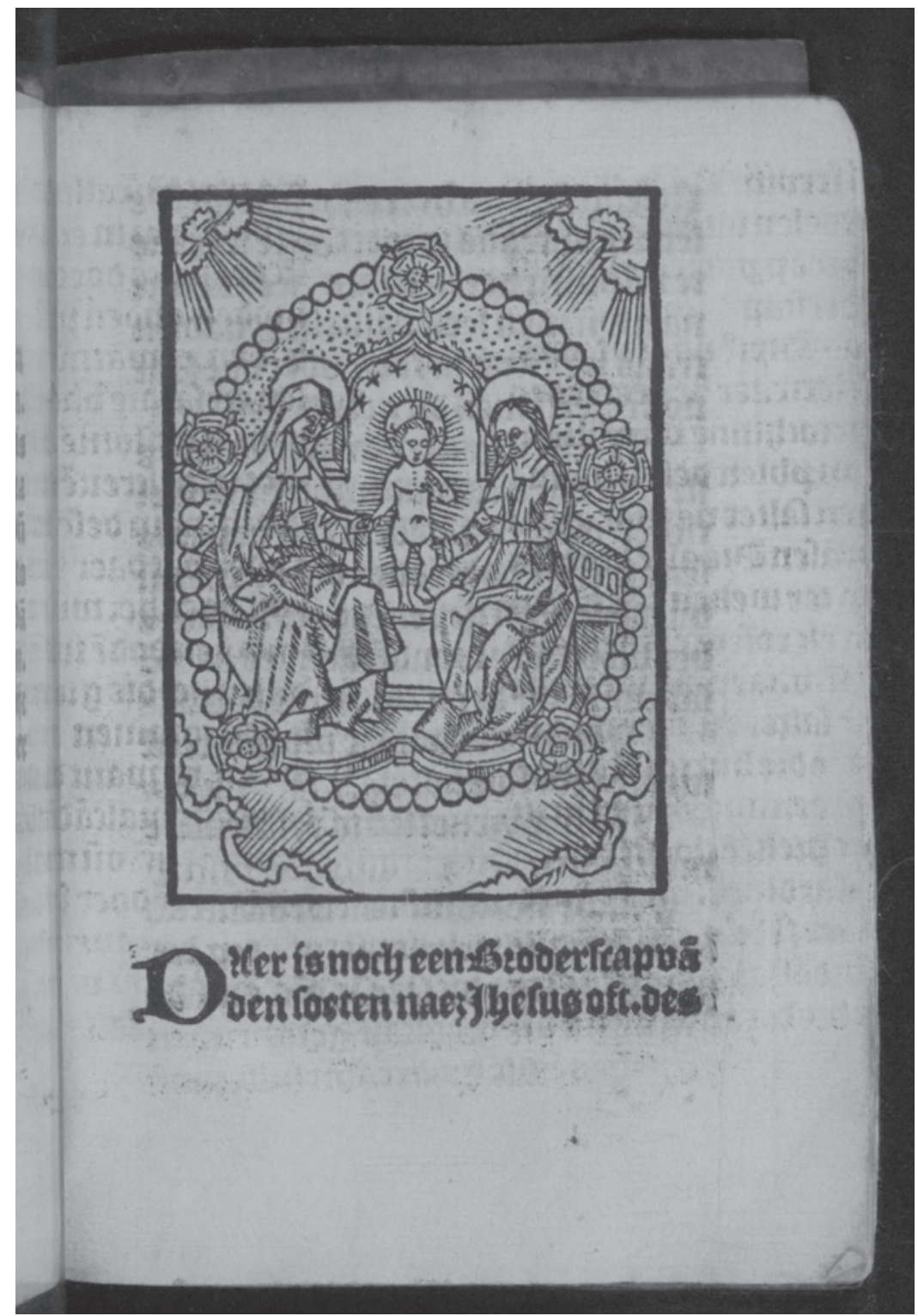

FIGURE 6.6 "Virgin and Child with St Anne surrounded by a rosary", woodcut illustration to Die costelike scat der geesteliker rijckdoem (Zutphen, Thieman Petersz.

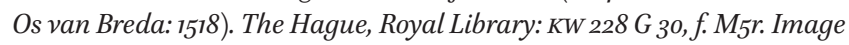
(C) ProQuest LLC. 
summoning to contemplate a particular anagogic element. Thus the fifth sequence connects Thursday to the carrying of the cross, gluttony, temperance and the contemplation of eternal punishment. However, compared to Everaert's play, the circumcision is missing. Instead, the treatise lists the aforementioned carrying of the cross. Moreover, it connects Wednesday to three instances or aspects of the ripping off of Christ's clothes, linking each to a particular form of greed. Finally, references to the days of the week and the virtues are altogether missing in Everaert's play. Another option would be a treatise that also deals with the seven blood-sheddings and does include the circumcision: Een devote oeffeninge tot eenen Yegelycke choor der engelen (A Devout Exercise on Each of the Choirs of Angels) ${ }^{86}$ However, this booklet does not link Christ's sufferings to any of the cardinal sins. As far as the blood-sheddings are concerned, Everaert might also have drawn inspiration from a treatise on the fifteen blood-sheddings: Die xv. bloetstortinghen Ons Lieven Heren Jhesu Christi (The Fifteen Blood-Sheddings of Our Dear Lord Jesus Christ), ${ }^{87}$ which consists of a series of prayers to these sufferings interspersed by one Pater Noster and one Ave Maria. All seven blood-sheddings that Evaert mentions are found among the fifteen listed here. All prayers, though, refer to sinning in a general way, and none makes a specific connection between a blood-shedding and a cardinal $\sin .88$

Yet what comes closest in approach to Everaert's play is a small treatise whose title does not betray any connection to the seven blood-sheddings at all: Die figuren vanden seven kercken van Romen (The Figures of the Seven Churches of Rome). ${ }^{89}$ On its first page it says that it concerns a number of prayers said within the confraternity of the Dominican friars of Haarlem, which are each connected with a particular indulgence. It was meant to help its readers gain indulgences by mentally visiting the seven pilgrim churches of Rome. They were stimulated to do so by looking at seven woodcuts, printed on each left page of the open booklet, representing these churches [Fig. 6.7]. Their walls are carved open like stages in order to allow the reader to look inside and meditate on two scenes depicted in each of them. One is related to the church's patron saint, the other is a representation of one of Christ's blood-sheddings.

86 Delft, Henric Pietersz. Lettersnijder, 1508-1511; ex. Amsterdam, University Library, отм: Ned. Inc. 86 (NK 1610).

87 Antwerp, Jan van Ghelen, 1524; The Hague, Royal Library, KW 229 G 23 (N K 425).

88 A comparable list appears in the Hortulus anime in duytsche (Garden of the Soul in Dutch), Antwerp, Willem Vorsterman, 1526; The Hague, Royal Library, KW 151 D 26 (NK 4241).

89 Utrecht, J. Berntsz., c. 1526 or earlier; The Hague, Royal Library, KW 228 G 28 (N K 1283). 


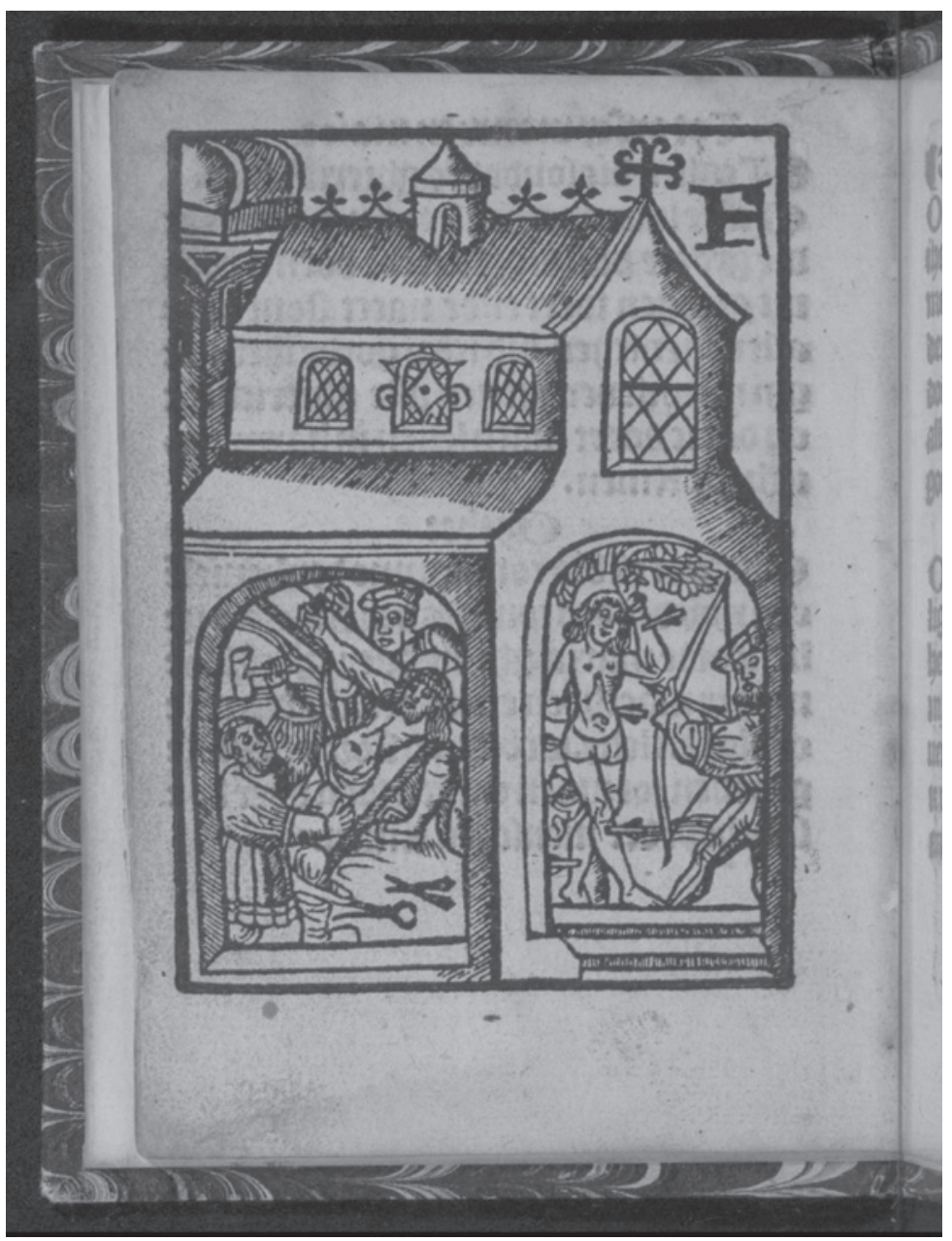

FIGURE 6.7 "The Church of St Sebastian", woodcut illustration to Die figuren vanden seven kercken van Romen (Utrecht, J. Berntsz., c. 1526 or earlier). The Hague, Royal Library, KW 228 G 28, f. A6v. Image (c) ProQuest LLC.

On each right page two prayers are printed, one to Christ and one to the patron saint. Not only does each prayer contain a graphic description-however short—of each of Christ's sufferings, thus stimulating the devotees' immersion in his Passion, but they also start with a reference to one of the seven cardinal sins. ${ }^{90}$ The blood-sheddings are mentioned in the same order as in Everaert's

9o The woodcuts are similar to those in a treatise with a virtually identical title: Van die seven kercken van Romen (About the Seven Churches of Rome), attributed to Robertus Coelen, that is, the Benedictine monk Rupert of Deutz (c. 1075-1130); Antwerp, Willem

For use by the Author only | (C) 2015 Koninklijke Brill NV 
play, and are connected to almost the same vices. Whereas Everaert connects the flagellation to envy and the piercing of the side to wrath, the treatise does it the other way around. ${ }^{91}$ Apart from the printed prayers, readers had to say one of the seven penitential psalms and meditate on one of the Stations of the Cross. ${ }^{92}$ They were stimulated to do so by the woodcuts, each of which, apart from a pilgrim church, depicted a Station. As Stations the author chose the seven blood-sheddings. Not being a Station of the Cross, the circumcision was left out.

\section{Conclusion}

It seems likely that Everaert's table plays were informed by his reading experience of devotional treatises and by his ability to visualize this experience through writing, in this case through the composition of plays. This seems particularly true in the case of the play on the seven blood-sheddings. The booklets mentioned clearly called for a performative reading. They invited an active process of reenactment through visualization. They certainly incited their readers to action, by saying prayers. Both table plays intended to stimulate their audience's performance literacy, in the sense that they demonstrated how to encounter and deal with a devotional object's (or devotional image's) material actuality, in casu with a rosary or a representation-in one form or another-of the Passion of Christ.

Vorsterman, 1521; ex. The Hague, Royal Library, KW 2901 E 25 (NK 3313). This work can be called devotional in the sense that it provides the potential pilgrim to Rome with a description of these churches, a travel guide almost, adding details of indulgences to be gained by visiting them. The description is preceded by a calendar listing all indulgences connected to various stations and locations in Jerusalem, as well as the feasts of various saints. Although this treatise represents the blood-sheddings in an almost identical manner as its near namesake, it does not mention them, nor does it contain prayers and references to the vices.

91 It should be noted that two blood-sheddings are represented in the wrong order. The fourth woodcut (lettered E instead of D) shows the ripping off of clothes (and not the crowning with thorns), whereas the fifth (lettered D instead of E) shows the crowning with thorns (and not the ripping off of clothes). The woodcuts in Van die seven kercken van Romen show the blood-sheddings in the correct order: the crowning with thorns first, and then the ripping off of clothes. However, in this series the sweating of blood is shown before the circumcision.

92 On the performative praying of the penitential psalms, see Sutherland A., "Performing the Penitential Psalms in the Middle Ages", in Gargnolati M. - Suerbaum A. (eds.), Aspects of the Performative in Medieval Culture (Berlin - New York: 2010) 15-37. On their role in penitential practice, see King'oo C.C., Miserere Mei. The Penitential Psalms in Late Medieval and Early Modern England (Notre Dame, IN: 2012) 8-19.

\section{For use by the Author only | (C) 2015 Koninklijke Brill NV}


Table plays fit into the sixteenth-century convivium tradition, meaning that the content of these plays supposedly became the subject of conversation and deliberation among the audience after the performance had ended. Already during its staging the dinner guests were challenged to get intellectually involved by trying to unravel the identity of the presents and to understand their allegorical meanings and connections. One could say that the dramatic performance constituted a play within a play, the latter being the banquet itself, with the banqueters as actors. ${ }^{93}$ The guild's king was the main character in both, as the principal dinner guest probably sitting in the middle of the table and as addressee of the play. Especially in the Play on the Seven BloodSheddings, he is being involved in it almost from the outset. The plays, again especially that on the blood-sheddings, belong to the kind of vivid demonstrations - in line with the rhetorical principle of enargeia - that enlivened the early modern dinner party. ${ }^{94}$

\section{Bibliography}

Areford D.S., The Viewer and the Printed Image in Late Medieval Europe (Farnham Burlington, VT: 2010).

Blau S., "Performative Literacy: The Habits of Mind of Highly Literate Readers", Voices from the Middle 10 (2003) 18-22.

Brantley J., Reading in the Wilderness. Private Devotion and Public Performance in Late Medieval England (Chicago - London: 2007).

Brown A., Civic Ceremony and Religion in Medieval Bruges c. 1300-1520 (Cambridge: 2011). Bryan J., Looking Inward. Devotional Reading and the Private Self in Late Medieval England (Philadelphia: 2008).

Bynum C.W., Holy Feast and Holy Fast. The Religious Significance of Food to Medieval Women (Berkeley - Los Angeles: 1987).

Dumolyn J. - Haemers J., "Let each man carry on with his trade and remain silent'.

Middle-class ideology in the urban literature of the late medieval Low Countries", Cultural and Social History 10 (2013) 169-189.

Ehrstine G., "Framing the Passion: mansion staging as visual mnemonic", in Gertsman, Visualizing Medieval Performance 263-277.

—_ "Passion Spectatorship between Private and Public Devotion", in Gertsman E. -

Stevenson J. (eds.), Thresholds of Medieval Visual Culture: Liminal Spaces (Woodbridge: 2012) 302-320.

93 Goldstein C., Pieter Bruegel and the culture of the early modern dinner party (Farnham Burlington, VT: 2013) 5, 78 . 
Falkenburg R.L., The Fruit of Devotion. Mysticism and the imagery of love in Flemish paintings of the Virgin and Child, 1450-1550 (Amsterdam - Philadelphia: 1994).

Freedman P., Out of the East. Spices and the Medieval Imagination (New Haven \& London: 2008).

Gertsman E. (ed.), Visualizing Medieval Performance: Perspectives, Histories, Contexts (Aldershot - Burlington, vT: 2008).

- "Introduction: the spectrum of performances", in Gertsman, Visualizing Medieval Performance 1-13.

Goldstein C., Pieter Bruegel and the culture of the early modern dinner party (FarnhamBurlington, VT: 2013).

Harbison C., "Visions and Meditations in Early Flemish Painting", Simiolus 15 (1985) $87-118$.

Hummelen W.M.H., Repertorium van het rederijkerdrama 15oo-ca. 1620 (Assen: 1968).

Hüsken W., “'Van Incommen en begheert men Scat noch Goet': Cornelis Everaert and the Rosary", in Gosman M. - Walthaus R. (eds.), European Theatre 1470-160o. Traditions and Transformations, Mediaevalia Groningana 18 (Groningen: 1996) 119-129.

__ , "De gelegenheidsdichter Cornelis Everaert en zijn tafelspelen in enge en ruimere zin”, Verslagen en Mededelingen van de Koninklijke Academie voor Nederlandse Taal- en Letterkunde (1992) 62-78.

- "Cornelis Everaert and the community of late medieval Bruges", in Hindley A. (ed.), Drama and Community: People and Plays in Medieval Europe, Medieval Texts and Cultures of Northern Europe 1 (Turnhout: 1999) 110-125.

(ed.), De Spelen van Cornelis Everaert, 2 vols. (Hilversum: 2005).

Jékely Z., "Maiolica Jugs in late Medieval Painting", in Balla G. - Jékely Z. (eds.), The Dowry of Beatrice - Italian Maiolica Art and the Court of King Matthias (Budapest: 2008) 55-66.

Keenan W.J.F. - Arweck E., "Introduction: Material Varieties of Religious Expression”, in Arweck E - Keenan W.J.F. (eds.), Materializing Religion. Expression, Performance and Ritual (Farnham - Burlington, vT: 2006) 1-20.

King R., “'The Beads with Which We Pray Are Made from It': Devotional Ambers in Early Modern Italy", in De Boer W. - Göttler C. (eds.), Religion and the Senses in Early Modern Europe, Intersections: Interdisciplinary Studies in Early Modern Culture 26 (2012) (Leiden - Boston: 2013) 153-175.

King'oo C.C., Miserere Mei. The Penitential Psalms in Late Medieval and Early Modern England (Notre Dame, IN: 2012).

Kramer B., "Verbondenheid verbeeld. Over de uitbeelding van een rozenkranssnoer op een schilderij van de Meester van Sint-Goedele", Ons Geestelijk Erf 82 (2011) 136-159.

Mareel S., Voor vorst en stad. Rederijkersliteratuur en vorstenfeest in Vlaanderen en Brabant (1432-1561) (Amsterdam: 2010).

Newman B., "What Did It Mean to Say 'I Saw'?", Speculum 80 (2005) 1-43.

Pfaff R.W., New Liturgical Feasts in Later Medieval England (Oxford: 1970). 
Pikhaus P., Het tafelspel bij de rederijkers, 2 vols. (Ghent: 1988).

Ramakers B., "Discerning Vision. Cognitive Strategies in Cornelis Everaert's Mary Compared to the Light (c. 1511)", in Melion W.S. - Wandel L.P. (eds.), Image Theory and Incarnation Doctrine, Intersections: Interdisciplinary Studies in Early Modern Culture (Leiden - Boston: 2015) (forthcoming).

Ritz G., “Der Rosenkranz”, in 5oo Jahre Rosenkranz (Cologne: 1975) 51-101.

Scholliers P., "Meals, food narratives, and sentiments of belonging in past and present", in Scholliers P. (ed.), Food, drink and identity. Cooking, eating and drinking in Europe since the Middle Ages (Oxford - New York: 2001) 3-22.

Schuler C.M., "The Seven Sorrows of the Virgin: Popular Culture and the Cultic Imagery in Pre-Reformation Europe, Simiolus 21 (1992) 5-29.

Schulten W., "Das Rosenkranzgebet”, in 5oo Jahre Rosenkranz (Cologne: 1975) 122-127.

Scribner B., "Popular Piety and Modes of Visual Perception in Late-Medieval and Reformation Germany", The Journal of Religious History 15 (1989) 448-469.

Sheingorn P., "Performing the illustrated manuscript: great reckonings in little books", in Gertsman, Visualizing Medieval Performance 57-82.

Stevenson J., Performance, Cognitive Theory, and Devotional Culture. Sensual Piety in Late Medieval York (New York: 2010).

Strohm R., Music in Late Medieval Bruges (Oxford: 1990).

Sutherland A., "Performing the Penitential Psalms in the Middle Ages", in Gargnolati M. Suerbaum A. (eds.), Aspects of the Performative in Medieval Culture (Berlin - New York: 2010) 15-37.

Thoen I., Strategic Affection? Gift Exchange in Seventeenth-century Holland (Amsterdam: 2007).

Tomasik T.J. - Vitullo J.M., "At the table. Metaphorical and material cultures of food in medieval and early modern Europe", in Tomasik T.J. - Vitullo J.M. (eds.), At the table. Metaphorical and material cultures of food in medieval and early modern Europe (Turnhout: 2007) XI-XX.

Veblen T., The theory of the leisure class. An economic study of institutions (New York: $1961[1934])$.

Williamson B., "Sensory Experience in Medieval Devotion", Speculum 88 (2013) 1-43.

Williamson E., "Mere Properties. The Materiality of Religious Objects", in Williamson E. (ed.), The Materiality of Religion in Early Modern English Drama (Farnham Burlington, VT: 2009) 1-32.

Winston-Allen A., Stories of the Rose. The Making of the Rosary in the Middle Ages (University Park, PA: 1997).

Winter J.M. van, Spices and Comfits. Collected Papers on Medieval Food (Blackawton, Totnes: 2007). 